\title{
The Workings of International Commercial Arbitration (ICA)*
}

\section{Chinwe Egbunike-Umegbolu**}

\begin{abstract}
International commercial disputes require a significant and expeditious determination as enormous sums are approximately involved. Customarily, such disputes are settled through litigation, which was the only door. However, in modern times, with the growth of other dispute resolution methods, parties to an international commercial agreement have at their fingertips a different range of choices for the settlement of their dispute. One such method is arbitration, which is frequently utilised in modern-day international commerce because of its attractions and popularity.

Consequently, this paper weighs in on these attractions or advantages of arbitration in comparison with litigation. It will also explore the nature, processes and features of ICA, which has drawn parties to international trade agreements to resort to arbitration. However, there are drawbacks, especially the issue of cost and delay that affect efficiency in arbitration. Does this drawback take away the beauty of arbitration? This paper has recourse to questionnaires and laws collected from various Arbitral bodies via email as well as primary and secondary data to analyse this drawback. The conclusion reveals the current satisfaction with the system while at the same time analysing the challenges raised.
\end{abstract}

Keywords: Alternative Dispute Resolution; Arbitration, Arbitral bodies, Access to Justice; Litigation.

Received: April 21, 2021

Accepted: May 25, 2021

\footnotetext{
* Poster Presentation at the SLSA Conference 2021- Cardiff University United Kingdom.

${ }^{* *} \mathrm{PhD}$ student and a Part-time lecturer at the University of Brighton, School of Business and Law. c.umegbolu@brighton.ac.uk. ORCID ID: 0000-0003-3666-0441

DOI:10.51655/ejl.2021.5
} 


\section{The Workings of International Commercial Arbitration (ICA)}

\section{Introduction}

Disputes are inevitable in human existence, whether human frailties, whether mismanagement or over-expectation will always interfere with contractual performance. ${ }^{1}$ Thus, the institutional centres of arbitration and states have modernised their laws and set up various arbitration centres to keep up with the surge of business. ${ }^{2}$ Amongst all this activity, it can easily be forgotten that arbitration is an easy and simple method of resolving disputes. For instance, parties in a dispute can agree to resolve their conflict or disagreement through an appointed impartial third party that they trust. ${ }^{3}$ This third party (the arbitrator) listens to the evidence and then makes a final decision, which is binding on the parties. Often, these decision leads to a final, binding and enforceable award. ${ }^{4}$ This process is preserved in confidentiality, thus making sure that the parties' issues or disputes are unknown to the public. On the other hand, their privacy can be disclosed or breached with the consent of the parties or pursuant to the order of the court. ${ }^{5}$

In support of the above viewpoint, is the judicial decision in $A l i$ Shipping Corp v Shipyard Trogir ${ }^{6}$ where the court emphasised on the Dolling-baker ${ }^{7}$ principle that arbitral parties are subject to an implied duty of confidentiality. ${ }^{8}$ However, the court made some exceptions to the implied duty of confidentiality, namely:

a) "by leave of the court,"

\footnotetext{
${ }^{1}$ Julian Lew, Loukas Mistelis, Stefan Kroll, Comparative International Commercial Arbitration (Kluwer law International 2003) .1.

2 Ibid

${ }^{3}$ David Sutton, Judith Gill, Matthew Gearing, Russell on Arbitration $\left(23^{\text {rd }}\right.$ edn, Sweet \& Maxwell 2007) 6.

${ }^{4}$ Susan Blake, Julie Brown, Stuart Sime, A Practical Approach to Alternative Dispute Resolution ( $2^{\text {nd }}$ edn, Oxford University Press 2011) p. 31.

${ }^{5}$ Dolling-Baker v Merrett [1990] 1 WLR 1205.

${ }^{6}$ [1997] EWCA Civ 305

${ }^{7}$ [1999] EWCA 1WLR 314

${ }^{8} \operatorname{Ibid}($ n.5)
} 
b) "Where disclosure is made pursuant to the express or implied consent of the party who originally produced the material."

Flowing from the above, arbitration proceedings apart from the above exceptions are unquestionably private though endorsed by law. ${ }^{10}$ For instance, any document produced in the arbitral tribunal shall be bound to confidentiality; this indicates its commitment to making arbitration private $^{11}$. On the contrary, this cannot be said about litigation, which is Public. $^{12}$

\section{The Inherent Nature, Processes and Features of Commercial Arbitration}

Similarly, parties in arbitration have the choice to select the number of arbitrators and appoint an arbitrator that is an expert on the subject matter of disputes. ${ }^{13}$ This is an essential factor in arbitration because an arbitrator's approach to procedural and substantive issues will impact heavily on the outcome of the dispute. ${ }^{14}$ Thus, appointing an arbitrator is an essential step towards representing a party in the arbitration. The parties power to choose the arbitral tribunal is what gives arbitration an edge over the national courts. ${ }^{15}$ Leveraging on this, it provides a major difference between arbitration and litigation.

Gary Born pointed out that parties are given autonomy or the choice with the decision to select the seat of arbitration, the substantive law, and the language of the contract. ${ }^{16}$ On the other hand, Margaret Moses

\footnotetext{
${ }^{9}$ Ibid (n.6)

${ }^{10}$ Article 3 IBA rules

${ }^{11}$ Ibid

${ }^{12}$ John Tackaberry, Arthur Marriot, Bernstein's Handbook of Arbitration and Dispute Resolution Practice $\left(4^{\text {th }}\right.$ edn, Volume 1 Sweet \& Maxwell in Conjunction with the Chartered Institute of Arbitrators 2003) 15.

${ }^{13}$ Chnwe Umegbolu, Careers in ADR with Professor Emilia Onyema https://blogs.brighton.ac.uk/chinwe/2021/03/13/episode-15-careers-in-adr-with-professoremilia-onyema/ accessed $5^{\text {th }}$ April 2021

${ }^{14}$ Ibid

${ }^{15}$ Ibid

${ }^{16}$ Born, Gary, International Litigation \& Arbitration The Principle of Judicial Non Interference in International Arbitral Proceedings (Penn Law: Legal Scholarship Repository)
} 


\section{The Workings of International Commercial Arbitration (ICA)}

revealed that 'Parties also get to decide whether the resolution of their disputes will be administered by an arbitral institution which has the advantage of having more credibility because award rendered under a well-known institution is widely recognised in the international community and the courts. ${ }^{17}$ However, they can opt for ad hoc, which offers more flexibility in the proceedings and is cost-effective because there is no administering institution. ${ }^{18}$

In the light of the views above, it suggests that arbitration is relatively quick because once an arbitrator has been selected or once the parties select any arbitral body of their choice then proceedings can commence immediately. Unlike in litigation where a case has to wait till whenever the judge has the time to hear it, it might even take a month or even a decade to be heard. ${ }^{19}$

Additionally, the points made above, signify that the fundamental factor of the national court, which differs from an arbitral tribunal, is the rigidity of its proceedings. ${ }^{20}$ This as it were is in contrast with the degree of autonomy bestowed on the parties by arbitration. Thus under the rules of arbitration and the rules of contract, a party to an agreement has the right and freedom to suggest any term he wishes to be included in the contract. ${ }^{21}$ This has received judicial backing in the case of Printing and Numerical Registry Co v Sampson, where the court held that 'public policy requires that an adult of full age and understanding has the freedom to enter into a contract and that the contract shall be enforced by the court.' 22 This further supports the fact that arbitration

1005.

\footnotetext{
${ }^{17}$ Margaret Moses, The Principles and Practice of International Commercial Arbitration (2 $2^{\text {nd }}$ edn, Cambridge University Press 2012) 1.

${ }^{18}$ Ibid

${ }^{19}$ Umegbolu, Chinwe, To What Extent is Arbitration a Cheaper and more Efficient Process of Dispute Resolution-in Comparison to Litigation? (LLM Dissertation submitted to Kingston University London) .56

${ }^{20}$ Gary Born, Keynote Address: Arbitration and the Freedom to Associate, Ga. J. Int'l \&

Comp. L 2009.16

${ }^{21}$ Ibid

22 [1982] EWCA Civ. 5.
} 
empowers parties with enormous freedom and control to choose a seat of law that will govern the arbitration aside the confines of their jurisdiction.

One of the essential elements of Arbitration is its consensual nature, which has made it more attractive, more popular and has attracted more users to arbitrate. Thus, it constitutes the fundamental distinction between arbitration and litigation. However, it limits the powers of the arbitrator, due to the fact that the arbitrator will only decide on the issue that was covered in the arbitration agreement. On the contrary, a national court can settle any issues that parties do not agree to arbitrate. ${ }^{23}$ It is essential to point out that disputes can be resolved in two ways, either by their written agreement; willingly deciding to submit to arbitration from the onset or parties can still agree after a dispute has arisen, referred to as the submission agreement. ${ }^{24}$ In order words, arbitration exemplifies simple procedure, due process and swift justice. It is inherently non-coercive and private. ${ }^{25}$

In hindsight it enables parties to resolve -past issues and address future needs by providing them with party autonomy where they can stipulate what they want and how they want it in their contractual agreement. ${ }^{26}$ Unlike in litigation, it has been argued that most cases have only benefited the rich because of the complexity involved in the filing of cases in the high court and waiting for the case to be heard. ${ }^{27}$ In this regard, clients with low income will find out that they are left with nothing after being burdened with a large number of fees to commence litigation. This is an area that involves a considerable deal of

\footnotetext{
${ }^{23}$ Henry Silberberg, Marlene Pontrelli, To Arbitrate or Not to Arbitrate? (1983) Preventive Law Reporter p. 68-69.

${ }^{24}$ Ibid

${ }^{25}$ Umegbolu, Chinwe, Dispensation of Justice: Lagos Multi-Door Courthouse (LMDC) as a case study (On-going research University of Brighton) . 45

${ }^{26}$ Ibid (n16)

${ }^{27}$ Chinwe Umegbolu, Behind the legal frustration

$<$ https://research.brighton.ac.uk/en/publications/behind-the-legal-frustration> accessed 5th February 2020
} 


\section{The Workings of International Commercial Arbitration (ICA)}

expenditure on the part of the clients that makes litigation to be an unattractive first choice.

Subsequently, another exciting feature of arbitration is the validity of an arbitration agreement for it to be valid; it has to be in writing and signed by the parties. ${ }^{28}$ Article II (1) (2) (3) of the New York Convention has provided the requirement to support the fact that the writing requirement must be vital. In most cases, a signature will be required, the disputes must be in a defined legal relationship, and the matter must be settled in arbitration unless the agreement is null and void, inoperative or incapable of being performed. ${ }^{29}$

Furthermore, it is apt to point out that contracting member states are mandated to honour and enforce arbitration agreements that are in writing. ${ }^{30}$ So, the courts have a duty in most jurisdictions to stay proceedings and refer a matter to arbitration in situations where a party to a binding arbitration agreement commences an action in court in disregard to the arbitration agreement. ${ }^{31}$ Then the question of whether the agreement was in writing, signed and valid is most likely to occur as a recalcitrant party may decide to renege or back out from the contract to arbitrate. Though, even when an arbitration clause has fulfilled all the above requirements for validity, the issue of validity may still be raised if the main contract containing the arbitration clause has been dismissed. In such a situation, the arbitration clause will still be held to be valid based on the principle of separability. ${ }^{32}$

Another important aspect of arbitration is that it involves the submission of disputes to a non-governmental decision-maker selected

\footnotetext{
${ }^{28}$ The New York Convention 1958, Art.II (2).

${ }^{29}$ Ibid Article II.

${ }^{30}$ Ibid Article II.

31 [2007] EWCA Civ20.

${ }^{32}$ Susan Blake, Julie Browne, Stuart Sime, A Practical Approach to Alternative Dispute Resolution (2 $2^{\text {nd }}$ edn, Oxford University Press 2012) 396-397.
} 
by the parties. ${ }^{33}$ This is another way in which arbitration differs from the court-sponsored litigation. In arbitration the arbitrators are private citizens whereas, in litigation, judges preside and are paid by the government. Arbitrators, unlike judges, tend to be informal in their deliberation of proceedings, and their primary interest lies with the parties. $^{34}$

Additionally, arbitrators need not be lawyers, as the qualification to adjudicate varies from party to party. In some areas like the construction industry, architects and engineers with their technical knowledge have an edge to be selected as arbitrators because of their specialist knowledge. ${ }^{35}$

In summary, International arbitration provides a more neutral forum, speedy, and expert dispute resolution process, largely subject to the parties control in a single centralized forum, with internationally enforceable dispute resolution agreements and decisions. While far from perfect, international arbitration is rightly regarded as suffering fewer ills than litigation of international disputes in national courts and affording parties more practical, efficient and neutral dispute resolution than available in other forums.

\section{The Underlying Principles of International Commercial} Arbitration (ICA) Process

\section{Party Autonomy}

This is the fundamental basis of arbitration; this principle stipulates that parties have the utmost freedom to organise how their dispute should

\footnotetext{
${ }^{33}$ Gary Born, International Arbitration: Law and Practice (Wolters Kluwer Law \& Business 2012) 5 .

${ }^{34} \mathrm{Ibid}$

${ }^{35}$ Jane Jenkins, Simon Stebbings, International Construction Arbitration Law (Wolters Kluwer Law \& Business 2014) 200.
} 


\section{The Workings of International Commercial Arbitration (ICA)}

be resolved. ${ }^{36}$ This flows from the full feature or characteristics of arbitration, in that it is a consensual process founded on an agreement between the parties to refer their dispute to an impartial arbitral tribunal. ${ }^{37}$ The principle also provides freedom for parties to choose the substantive law, seat of arbitration, select the arbitral tribunal and the language of the arbitrators. Furthermore, these rights are implemented at the contract stage, or it may arise in future. ${ }^{38}$ Sunday Fagbemi succinctly captured it in the following sentence:

"The freedom of parties to consensually execute arbitration agreement is known as the principle of party autonomy. "39

It follows through that if parties choose the right law they are comfortable with, they will be able to open up during the session. For the following reasons, party autonomy curtails uncertainty and can be predictable. ${ }^{40}$ However, party autonomy triumphs when it is not in conflict with the mandatory provisions of the Arbitration Act 1996 that is the seat of arbitration. ${ }^{41}$ Hence, this provision in $S s 9-11, S 12, S s 75$, is an essential requirement to provide a mechanism for limited court interference to avoid errors or arbitrators acting without jurisdiction. ${ }^{42}$

It is vital to point out that the UK highest courts are in support of autonomy and flexibility in arbitration. The English Supreme Court case of Jivraj $v$ Hashwani $^{43}$ validated this position, where the court decided that the belief of an arbitrator is quite different from the obligations he must implement, as demonstrated in the Arbitration Act

\footnotetext{
${ }^{36}$ Fagbemi, Sunday, The Doctrine of Party Autonomy in International Commercial Arbitration: Myth or Reality? The Journal of Sustainable Development Law and Policy 2015 Vol. 6, 1224

${ }^{37}$ Ibid (n23)

${ }^{38}$ Alan Redfern, Martin Hunter, et al, Law and Practice of International Commercial Arbitration (4 ${ }^{\text {th }}$ edn, Sweet \& Maxwell 2004) 316.

${ }^{39}$ Fagbemi, Sunday, The Doctrine of Party Autonomy in International Commercial Arbitration: Myth or Reality? The Journal of Sustainable Development Law and Policy 2015 Vol. 6, 1225

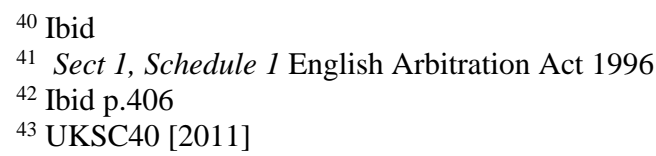


1996, are essentially not consistent in particular with an employment relationship. This implies that an arbitrator must be neutral and must be impartial towards the parties. ${ }^{44}$ This further emphasized that one of the distinctive elements of international arbitration is the broad freedom of choice enjoyed by the parties and the arbitrator to streamline the process for an effective and reliable means of settling a dispute, as indicated in section 1 of the Arbitration Act. ${ }^{45}$ It signifies that one of the attributes of arbitration and its popularity is the choice for a party to select an arbitrator and count on the neutrality of the process; this alone motivates and increases the confidence of its users.

It is evident that arbitration has an autonomous freedom of contract, then the provision mentioned above, should not be a hindrance but rather facilitate the parties to attain or fulfil their choices. To put it more simply, without this element mentioned above, arbitration will not be considered as efficient and a cheaper alternative to litigation.

\section{Separability}

On the other hand, Margaret Moses revealed that an 'arbitration clause is part and parcel of the arbitration agreement', yet under most rules, regulations and jurisdictions it is still referred to as a separate agreement because they are essentially independent of each other. ${ }^{46}$

On the contrary, Professor Emilia Onyema highlighted Agreements can be in the form of a pre-dispute clause in a contract or a separate submission agreement covering the disputes that have

\footnotetext{
${ }^{44}$ [2011] UKSC 40.

${ }^{45}$ Arbitration Act 1996, Section 1.

${ }^{46}$ Section 12 (2) of Arbitration and Conciliation Act of Nigeria (ACA) cited in Onyema, Emilia, The Doctrine of Separability Under Nigerian Law (2009). SOAS School of Law Research Paper No. 03-2010, Apogee Journal of Business, Property \& Constitutional Law, Vol. 1, No. 1, 2009.69
} 


\section{The Workings of International Commercial Arbitration (ICA)}

already arisen. The principle of separability is most relevant to arbitration clauses contained in an underlying contract. ${ }^{47}$

What this means is that the individual clauses remain valid even where the primary agreement is invalid. As pointed above, in most jurisdictions, the principle of separability facilitates the arbitrators to hear and decide the dispute even if the main contact was vitiated by fraud and even if it was null and void from the onset. ${ }^{48}$ This demonstrates another significant difference with litigation and makes arbitration more attractive or a popular option. Whereas, if it were litigation and offences as serious as fraud is alleged it would in most cases terminate the proceedings.

On the other hand, if such a claim is raised, then it does not deprive the arbitrators of jurisdiction because it relates to the main contract and not specifically to the arbitration clause. In other words, from this writer's view, the whole point of separability is to allow the arbitrators to deal with the fallout from the main contract irrespective of fraud, which does not affect the arbitration agreement. ${ }^{49}$ Otherwise, parties would simply allege fraud and escape the arbitration agreement.

\section{Arbitrability}

Generally, for an arbitration agreement to be enforceable the subject matter must be arbitrable. For instance, the matter must be a subject that the state considers appropriate to be arbitrated.$^{50}$ In the first place, arbitration on its own would lack efficacy but for the support provided by the government-backed courts or it would be practically impossible to enforce awards that have been issued by the arbitral bodies but for the power provided by the court backed litigation. But to mention a few,

\footnotetext{
${ }^{47}$ Onyema, Emilia, The Doctrine of Separability Under Nigerian Law (2009). SOAS School of Law Research Paper No. 03-2010, Apogee Journal of Business, Property \& Constitutional Law, Vol. 1, No. 1, 2009.66

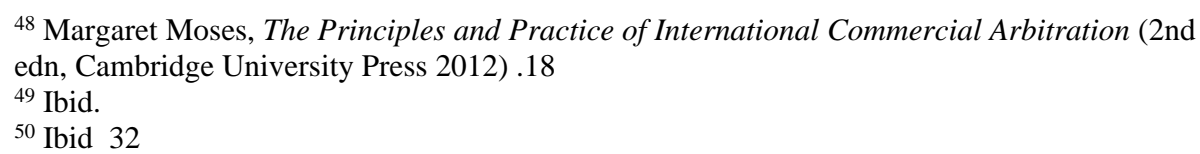


there are areas for which arbitration is ill suited for which litigation is well suited. ${ }^{51}$

However, Bermann stated that arbitrability connotes "any and all threshold issues' and on the other hand, the domain within the law permits arbitral decision making. "52

Therefore from the above statement, it implies that arbitrability is ambiguous depending on the issues raised. ${ }^{53}$ Hence, for arbitration agreement to be enforced the subject matter must be considered by the state to be arbitrable, that is issues bothering on criminal matters, child custody, family matters and bankruptcy are not arbitrable in most jurisdictions these can be referred to litigation. ${ }^{54}$ However, the issue of intellectual property due to the nature of confidentiality of arbitral proceedings helps to safe guide trade secrets -is arbitrable. ${ }^{55}$

In contrast, patent law might not be arbitrable because this is considered an issue of the courts, but on the other hand, disputes arising out of the agreement to license a patent would be arbitrable, because those disputes are basically contract disputes. ${ }^{56}$

Correspondingly, disputes involving antitrust laws, which were initially not arbitrable, are now arbitrated upon. ${ }^{57}$ Therefore, a mere illegality should not deprive the tribunal of jurisdiction to determine the dispute if it falls within its remit. ${ }^{58}$ Moreover, in the decided case of Fiona Trust $v$ Privalov ${ }^{59}$ where a contractual defect (illegality and fraud) was raised

\footnotetext{
${ }^{51}$ Umegbolu, Chinwe, To What Extent is Arbitration a Cheaper and more Efficient Process of Dispute Resolution-in Comparison to Litigation? (LLM Dissertation submitted to Kingston University London) .42

52 Jan Paulsson, The idea of Arbitration (Oxford University Press 2013) 72.

${ }^{53}$ George Bermann, The "Gateway" Problem in International Commercial Arbitration (2012) 37 (1) The Yale Journal of International law, 10-11

${ }^{54}$ Margaret Moses, The Principles and Practice of International Commercial Arbitration $\left(2^{\text {nd }}\right.$ edn, Cambridge University Press 2012) 31

${ }^{55}$ Ibid

${ }^{56}$ Fiona Trust Holding Corp v Privalov [2007] EWCA Civ. 20

57 Brewer, Thomas J. "The Arbitrability of Antitrust Disputes: Freedom to Contract for Alternative Forum.” Antitrust Law Journal, vol. 66, no. 1, 1997,. 91-126

${ }^{58}$ Ibid (n.49)

${ }^{59}$ [2007] EWCA Civ. 20
} 


\section{The Workings of International Commercial Arbitration (ICA)}

but it did not invalidate the arbitration agreement. The court upheld the application and referred the matter back to arbitration because it was not enough that bribery impeaches the whole contract. ${ }^{60}$ However, the only exception would be where bribery impeaches the whole arbitration clause itself. ${ }^{61}$

In furthrance, is the case of Ust-Kamenogorsk Hydropower Plant JSC v AES Ust-Kamenogorsk Hydropower Plant LLP, ${ }^{62}$ where the court held that the arbitration clause was stated to be invalid by Kazakhstan law because it was contrary to public policy. ${ }^{63}$ It then follows that section 44 of the 1996 Act and section 37 of Senior courts Act of 1981 will determine the scope of English court's jurisdiction to intervene. ${ }^{64}$ Therefore, an arbitration clause should be given a broader interpretation in order to cover any specific issues or all or any arising disputes that may arise between the parties.

\section{Null and Void}

Aside from the necessary provision provided by the New York convention for the enforcement of arbitration clauses, they provided some defences, which must be fulfilled before any court will decide to refer a party to arbitrate. ${ }^{65}$ Yet there is an exception to this general rule and this occurs when the agreement clause is null and void right from the beginning, such as there was no consent before the commencement of the contract agreement or the party was under duress or undue influence. As a result, the arbitration was void from the start. ${ }^{66}$

\footnotetext{
${ }^{60}$ Ibid

${ }^{61} \mathrm{Ibid}$.

62 [2013] UKSC 35

${ }^{63}$ Umegbolu, Chinwe, Case Review: The Validity of Arbitration Clause and Anti Suit Injunction Revisited (Research Brighton University 2019) 10

${ }^{64}$ Ibid

${ }^{65}$ New York Convention, Art.11 (3).

${ }^{66} \mathrm{Ibid}$
} 
The seat of arbitration is also an underlying principle in defining the legal framework of the arbitral process. ${ }^{67}$ If parties fail to specify or stipulate the seat of arbitration in clear terms, as well as the intentions of the parties not adequately conveyed or too distinct to be understood then the agreement becomes null and void. ${ }^{68}$

Following on the above point for the court to adequately pronounce a judgement or decision, the intentions of the party should be well known and meaningfully conveyed. Thus the arbitration agreement should be drafted with great care and this will have an enormous impact in the arbitral proceedings, it will undoubtedly enhance the efficiency and success of the process if well drafted.

The above view was supported in the Singapore case of HKL Group Co Ltd v Rizq Int. Holdings Pte Ltd, where a badly drafted arbitration clause took the court a long time to dissect what the parties intentions was, although the court later upheld the decision, stating that it was evident or obvious that the parties intention was to arbitrate. ${ }^{69}$ However, this was contrary, to the decision of the Swiss Supreme Court of $X$ Holding AG and Ors $V Y$ Investments $N V$ where the court overruled a pathological clause, for not adequately stating the intents of the parties to arbitrate. ${ }^{70}$

Indeed, when looking at the opposite decisions expressed by the different court above, it is essential to point out that in order for parties to avoid equivocal clause, the clear intention of the parties should be duly stated, plus the terms of the agreement must be broad and free from ambiguity, so as to avoid the misperception that may arise from imprecision. ${ }^{71}$ For example, such broad formula that is free from pathological clause was stated in the case of Governor of Gibraltar v

\footnotetext{
${ }^{67}$ Vial, Gonzalo, Influence of the Arbitral Seat in the Outcome of an International Commercial Arbitration Published in Cooperation with SMU Dedman School of Law 2017) .337

68 Ibid (n.49)

69 [2013] SGHCR 5.

70 [2010] SSC.

${ }^{71}$ Ibid
} 


\section{The Workings of International Commercial Arbitration (ICA)}

Kenny. ${ }^{72}$ Equally a good and standard arbitration clause should be constructed to cover all or any arising dispute or claim (anticipated or unforeseen). Also parties will also be in a position to be able to agree or choose an ad hoc or institutional, subject to their preferences which are tailor-made to the issues surrounding the transaction based upon any factors affecting the same. The London Court of International Arbitration (LCIA) has recommended a conventional model clause, which is as follows:

Any dispute arising out of or in connection with this contract, including any question regarding its existence, validity or termination, shall be referred to and finally resolved by arbitration under the LCIA Rules, which rules are deemed to be incorporated by reference into this clause. $^{73}$

It should also contain the seat of the arbitration (city or country) number of the tribunal, nature of the procedure, the cost distribution between the parties, and enforcement relating to any procedural matter, award and confidentiality clause. ${ }^{74}$ The rationale behind this is that if clauses are framed or inserted in an appropriate manner, the court will uphold it and arbitration will move forward according to its terms. Then efficient proceeding will continue to flourish in, arbitration and delay will be mired in the arbitral process. To put the above viewpoint in context, it should be mandatory for all arbitral agreements to contain a minimum accepted standard to avoid the vagaries of unacceptable standard discussed above.

Hence, there are so many factors that can vitiate the arbitration agreement as stated in this work, thus drafting of the arbitration agreement can contribute to delay and can complicate the enforcement of the arbitral award. Nevertheless, this can be avoided by drafting a

\footnotetext{
72 [1956] 2Q.B.410.

${ }^{73}$ LCIA- The London Court of International Arbitration 2010-2014 <https: //www.Icia.org/Dispute_Resolution>accessed 1 1t July 2019.

${ }^{74}$ Ibid
} 
short, broad and straightforward clause ${ }^{75}$, if it contains the very minimum requirements espoused earlier. Then there will be no need for an elaborate or complex clause that might further impede the efficacy of the arbitral proceedings.

\section{The Advantages of International Commercial Arbitration (ICA)}

$\mathrm{Tt}$ is essential to point out that the eagerness to use arbitration over litigation is because of the success stories in the last decades, not only is arbitration now the primary method of resolving investment disputes $;{ }^{76}$ it is also quite popular in the construction industry. ${ }^{77}$ This is evident in the statistical research carried out in 2013 by Remy Gaby and Loukas Mistelis indicated that $68 \%$ preferred using arbitration in the construction sectors and stated that it is more popular than litigation. ${ }^{78}$ However, concerns fuelled by recent events exist regarding both the economics and the consequence of the private dispute. Companies in London, especially, worry about qualified mediators and arbitrators, unnecessary delays, escalating costs that companies are venturing into every day. ${ }^{79}$ Despite these concerns, it seems that international arbitration and mediation can be cheaper, effective and practicable conflict management device for the growing number of complex, international commercial trades.

Apart from these reasons stated above, parties to an international commercial transaction frequently opt for arbitration because, of its dynamic nature, neutrality, simple procedure, final and binding award

\footnotetext{
${ }^{75}$ Margaret Moses, The Principles and Practice of International Commercial Arbitration $\left(2^{\text {nd }}\right.$ edn, Cambridge University Press 2012) 31.

${ }^{76}$ LCIA- The London Court of International Arbitration 2010-2014

<https: //www.Icia.org/Dispute_Resolution>accessed 1 1t July 2019.

77 Ibid

${ }^{78}$ Remy Gerby, Loukas Mistelis, International Arbitration Survey 2013: Corporate choices in International Arbitration (Queen Mary University London 2013) 2.

${ }^{79}$ Mark Appel, Taking Your Case to the International Centre for Dispute Resolution

(International Centre for Dispute Resolution) <https://www.adr.org> accessed $7^{\text {th }}$ July 2019.
} 


\section{The Workings of International Commercial Arbitration (ICA)}

and can be controlled by the parties. A number of these will be discussed in detail below:

Efficiency: It is often assumed that arbitration is quicker than litigation. Furthermore, in many cases, this is true. ${ }^{80}$ Conversely the fact that arbitrators can be selected due to party autonomy, and the separablity clause in arbitration, prevents a backlog of cases ${ }^{81}$. This cannot be said about litigation, in different countries and jurisdiction -the number of backlog of cases that can take years before a hearing date can be obtained.

On the contrary, in arbitration, within a short notice, parties can present their case to an arbitrator, and the matter will be resolved with great expedition. The easy access and efficiency of this method of dispute resolution, therefore easily lends itself to members of the public in particular commercial business men. ${ }^{82}$

Flexibility of the procedure: Due to the private nature of arbitration, the procedures can be amended at any time to suit the parties and characteristics of different cases. Hence, in recent years some of the institutional bodies like the (AAA) America Association of Arbitration, (LCIA) London court of International Arbitration, (SWISS) Switzerland and (ICC) International Chamber of Commerce, have amended their rules to provide for more effective and efficient management of the arbitration process. ${ }^{83}$ For example, the LCIA amended its rules, which include provisions of emergency arbitrators. ${ }^{84}$ This is an avenue of ensuring that parties to an international commercial arbitration can have an enhanced and expedited hearing. Besides, the

\footnotetext{
80 Julian Lew, Loukas Mistelis, Stefan Kroll, Comparative International Commercial Arbitration (Kluwer Law International 2003) 4.

81 Ibid

82 Julian Lew, Loukas Mistelis, Stefan Kroll, Comparative International Commercial Arbitration (Kluwer Law International 2003) 8.

${ }^{83}$ Summary of Changes Commercial Arbitration Rules (American Arbitration Association 2013) R-21<http://www.aryme.com/docs/adr> accessed 1st June 2019.

${ }^{84}$ London Court of Arbitration Rules <https://www.lcia.org/Dispute_Resolution_Services/lciaarbitration-rules-2020.aspx\#Article\%209B> accessed $22^{\text {nd }}$ January 2020
} 
continual growth of ICA as the preferred method was because most international contracts were drafted under the laws of England and coupled with the fact that parties can expand their dispute resolution options by requesting for mediation as an 'alternative' if the settlement is not reached in the arbitration agreement, taking cases in recent years to the institutional body has contributed to the recent development and use of arbitration in a different jurisdiction, especially in the UK.

Simple procedure: The simple procedure in the arbitration is an inherent advantage when compared to litigation. Indeed, arbitration can be faster and cost-effective means of settling disputes than litigation. This is because of the complicated and complex rules of taking of evidence, hearings, discovery, answering interrogatories and documents gathering, which can be used as delay tactics in litigation are significantly reduced in arbitration, which makes it faster and costeffective. ${ }^{85}$ This position was also supported by the survey of thirty (30) experienced lawyers conducted by the Herbert Smith City Firm.

Though, 'there was an increase in the mediated settlements offered, however, the key problems in litigation are related to evidential issues and cost in litigation. ${ }^{86}$ Whereas, in arbitration, it can be simple depending on the parties and the arbitral tribunal. The point stated above is supported by section 34 of the Arbitration Act 1999 and Article 1(4) IBA rules on taking of evidence in International Arbitration 2010, where both acts placed an enormous power on the tribunal to decide on matters as it deems appropriate pertaining to evidential issues. ${ }^{87}$ Due to the simple and limited procedure in arbitration unlike the full disclosure in litigation. This is one of the main reasons that parties are leaning or

\footnotetext{
${ }^{85}$ IBA Rules on the Taking of Evidence in International Arbitration (International bar Association 2010) Art 3.

${ }^{86}$ Neil Rose, Civil Procedure Rules: 10 Years Change (The Law Society Gazette 2014) <www.lawgazette.co.uk> accessed $2^{\text {nd }}$ July 2019.

${ }^{87}$ Ibid Article 4(1).
} 


\section{The Workings of International Commercial Arbitration (ICA)}

moving towards arbitration because matters are resolved quickly; this significantly reduces cost for disputants.

Moreover, the ability for parties to select expert arbitrators especially for disputes that arise out of specialist industries is an outright advantage over litigation, where it is unheard of, for parties to decide who would adjudicate over their matter. ${ }^{88}$ This also saves time and minimises cost, if parties to arbitral conflict act reasonable and discharge their obligation to each other. Unlike litigation where the judges, do not necessarily have the knowledge to handle disputes arising between parties from different countries or the ability to handle international business transactions and parties cannot influence who their judge might be, this by contrast is different with arbitration. ${ }^{89}$ The ability of parties to select experts from different fields makes the settlement of dispute faster and distinguishes international arbitration from litigation. ${ }^{90}$ However, the manner in which the parties exercise this freedom to select the arbitrators will determine if the arbitral process saves time and minimises cost. Essentially therefore, a lot of modalities depend on how party's act, but the important element has already been provided by the arbitral system. The eminent Swiss jurist and arbitrator Lalive stated, "Arbitration is only as good as its arbitrators. "91

This statement implies that, if parties choose a competent arbitrator that has a good knowledge of the subject matter and can effectively conduct proceedings and case management, then this would save time and cost. In fact, if steps are taken to enlighten the parties on an arbitrator's previous experience and skills, then the choice they make will help to determine how long a case will last, which in all probability might be quicker than litigation.

\footnotetext{
${ }^{88}$ Chinwe Umegbolu, Dispensation of Justice: Lagos Multi-Door Courthouse (LMDC) as a Case Study (Ongoing PhD research University of Brighton 2018-2021) 78.

${ }^{89}$ Ibid

90 Julian Lew, Loukas Mistelis, Stefan Kroll, Comparative International Commercial Arbitration (Kluwer Law International 2003) p.4.

${ }^{91}$ Lord David Hacking, 'Well, Did You Get the Right Arbitrator?' (2000) Mealey's International Arbitration Report . 32.
} 
Final and binding: The determination of parties' rights is another salient advantage of arbitration over litigation. This means that an arbitral decision becomes a final judgement that cannot be appealed. Subsequently, this cannot be challenged, except if the challenge falls within the eight defects of the New York Convention of $1958 .{ }^{92}$ This is contrast with litigation, where parties are free to appeal if they are not satisfied with the judgement passed, hence this will accelerate the cost in litigation. ${ }^{93}$

The Arbitral Institution: Arbitration can be perceived to be effective and cost efficient because of the mere reason that the arbitral proceedings have been streamlined to meet the needs of the parties. ${ }^{94}$ This is because of the changes made by different arbitral institutions by amending their rules to provide for an emergency arbitrator to be appointed at short notice to hear interim orders in their proceedings and has been immensely beneficial to parties. ${ }^{95}$ As a result reduces the interference of the state court, where parties wish to apply for interim measures subsequent upon the constitution of the arbitral tribunal. ${ }^{96}$ These changes are borne out of the fact that arbitration unlike litigation has the advantage of hindsight. This means that all the failings of litigation becomes the starting point for arbitration, as arbitration is seen as a remedy for most ills that plague litigation. ${ }^{97}$

\section{The Drawback or Challenges of International Commercial} Arbitration

Arbitration is generally recognized as a quick and cheaper alternative to resolve disputes hence its popularity. However, Drahozal suggests

\footnotetext{
${ }^{92}$ United Nations Convention on the Recognition and Enforcement of Foreign Arbitral Awards (New York Convention 1958) Article III \& IV (a) (b).

93 Stuart Sime, Derek French, Blackstone's Guide to the Civil Justice Reforms (Oxford University Press 2013) 1

${ }^{94}$ Ibid

${ }^{95}$ Mark Baker, James Rogers, Marion Edge (eds), Norton Rose Fulbright (1 International arbitration report 2013) 24.

${ }^{96}$ Ibid

${ }^{97}$ Ibid
} 


\section{The Workings of International Commercial Arbitration (ICA)}

that arbitration might be inefficient because in some cases it is cost consuming and frustrating. ${ }^{98}$ Thus, it has its drawbacks, which are the legal costs and backlog of cases similar to those in litigation. Generally, arbitration was flaunted as a more efficient and cost effective that results to a binding method of settling disputes. The rationale behind this flows from the U.S Supreme Court case of Mitsubishi Motors Corp. v. Soler Chrysler Plymouth that affirmed that following the speedy or efficient results of arbitration, which aids the needs of the parties hence the preference, of parties to arbitrate their disputes. ${ }^{99}$ In the USA, arbitration has been 'judicialized,' like litigation due to the huge cost associated with the latter. However, the proponents of arbitration posit that arbitration procedures are trailing the same path as litigation.

This writer suggests that the reason behind this is because arbitrators are determined on striking a balance of equality and efficiency. They may be hesitant to push parties to limit discovery, in anticipation of not upsetting anyone in mere hope that they will be appointed in future appointments. For this entire reasons arbitration hearings are now besieged with extensive discovery. ${ }^{100}$ For example, if Mrs PX provided for arbitration and did not stipulate in detail on how discovery will be handled then she might end up with a proceeding like litigation because the arbitrator may not want to impose his opinion on her. This was solely associated with litigation but has now been transferred to arbitration. This in turn has transformed arbitration process, which was designed to be a simple procedure into an expensive expenditure like litigation.

Thus, the recent case in Boxer Capital Corp v Jel Investments Ltd demonstrates that the disappointment of the proponents of arbitration to avoid cost and delay of the adversarial system was not attained in the above mentioned case which commenced in May 2013 and lasted till

\footnotetext{
${ }^{98}$ Christopher Drahozal, Arbitration Costs and Forum Accessibility: Empirical Evidence (2008) 41 U. Mich.JL. Reform 816.

99 [1985] 473U.S614, 633.

100 Thomas Stiponawich, Arbitration: The New Litigation (2010) University of Illinois Law Review12.213
} 
$27^{\text {th }}$ December 2018, more than five and half years after the dispute began. ${ }^{101}$ Therefore, it came as no surprise that parties and business counsel are moving towards mediation and other alternative means of dispute resolution that seems to be fruitful in attaining their goals.

Additionally, another challenge of arbitration is that parties cannot appeal even where it is obvious that the arbitrator decision was invalid. The point here is that the decision can be challenged for mainly procedural defects or illegality but cannot be challenged for example, for unfairness like a court case, though the arbitral process is designed to save time and cost at the same time deprives a party of his right to natural justice, equity and a good conscience and actually failed to adhere to natural justice is a reason to review it.

This practice was also resorted to in Nigerian Supreme Court case- $A g u$ $v$ Ikewibe where the court ruled that an award made in a customary arbitration, if the decision is mutually accepted by the parties, and then it is binding and res judicata. ${ }^{102}$ This decision of the Supreme Court in Nigeria was also in line with the decided Ghanaian case of Foliv Akese that once an award has been made based on the customary law that is repugnant to good sense for the losing party not to accept the decision of the arbitrators to whom he had previously agreed. ${ }^{103}$

Taking into account of the two decided cases above, it demonstrates that the courts in these two jurisdictions treat customary law arbitration precisely the same manner as statutory arbitration under the English law. Hence, parties that agreed to arbitrate will have no right to appeal even if the arbitrator has erred on law. Thus, parties are moving towards mediation because mediation costs are less costly and less adversarial than litigation. ${ }^{104}$ However, this disadvantage can be tampered by the

\footnotetext{
${ }^{101}$ [2013] BSCS 2366.

102 [1991] 3.N.W.L.R.

103 Virtus Igbokwe, The Law and Practice of Customary Arbitration in Nigeria: Agu v Ikewibe and Applicable Law Issues Revisited (2007) 41 Journal of African Law. 204.

104 Penny Brooker, Mediation Law: Journey through Institutionalism to Juridification (Routledge 2013) 9.
} 


\section{The Workings of International Commercial Arbitration (ICA)}

bare fact that parties have exercised their rights to arbitration and have conceded to whatever decision unlike litigation that is not voluntary.

In England in 2012, the court introduced new procedural code-Part1, Rule1.1 (1) (2, $a, b, c, d)$ with the overriding objective of the court, which aids the court to deal with cases of fairness and proportionate cost. This provision ensures that potential litigants are on equal footing, by minimising cost and dealing with cases proportionately. ${ }^{105}$ The above-mentioned provision was put in place in a bid to decongest the court, and the court system has improved in so many ways. For example, in some jurisdictions like Nigeria, in recent times the courts have an inbuilt out of Court Mechanism or Court-Annexed Alternative Dispute Resolution (ADR) processes which settles dispute between parties without going into the full trial of litigation. ${ }^{106}$ Hence, the Nigerian legal system in most states has provided an efficient solution to the issue of delay that has plagued the legal system for many years. ${ }^{107}$

However, in most cases, the arbitral tribunal has no power to join new parties to their proceedings ${ }^{108}$. The reason behind this is that all parties may be involved in various stages of the dispute and the tribunal's power must spring from the consent or agreement of the parties. ${ }^{109}$ Thus, if a party has not consented to arbitrate, then it implies that he cannot be joined in the arbitration. ${ }^{110}$ Consequently, a court generally has a right to consolidate similar claims of different parties; hence it is more efficient for the concerned parties, unlike the tribunal who does not have such powers. ${ }^{111}$

\footnotetext{
${ }^{105} \operatorname{Ibid}(\mathrm{n} 58)$

${ }^{106}$ Ibid

${ }^{107}$ Umegbolu, Chinwe, The Lagos Multi-Door Courthouse (LMDC) in Nigeria (Edublog Brighton 2019)

${ }^{108}$ London Court of Arbitration Rules

$<$ https://www.lcia.org/Dispute_Resolution_Services/lcia-arbitration-rules-

2020.aspx\#Article\%209B > accessed $22^{\text {nd }}$ January 2020

${ }^{109}$ Ibid (n90)

${ }^{110} \mathrm{Ibid}$

${ }^{111} \mathrm{Ibid}$
} 
In other words, the challenges of arbitration are somewhat similar to the advantages of litigation; therefore, the parties from the onset should carefully consider the controversy that may arise before consenting to arbitration agreement. ${ }^{112}$ The rationale behind this is that it is not all cases or issues that are suitable for arbitration. Unfortunately, from the challenges or drawbacks stipulated above, arbitration is far from performing a miracle to a cheaper and efficient alternative to litigation.

\section{Conclusion}

This work has explored the features, underlying principles, advantages and challenges of International Commercial Arbitration and it is concluded that this process has its attraction to users who seek settlement of disputes particularly in international trade disputes. It has shown to a large extent that arbitration is cheaper and a more efficient method of resolving disputes than litigation due to the facilitation of party autonomy and procedural flexibility.

However, this paper has further revealed that there are challenges posed by the process that can make it slow and inefficient. In some cases, an unwilling party may decide to hinder the process by raising the elements stated above, and in most cases, the challenges of arbitration become the advantages of litigation. Hence if parties decide to select the institutional litigation, this has its drawbacks, as parties are not free to select judges or procedure(s) in court. Further to this, even though the award in ICA is final and res judicata, the court must enforce it, which is where the strength of the adversarial process comes in.

On the contrary, these challenges or drawback can be avoided if the parties select the institutional arbitration, which has a detailed procedure, restrictions and control. Because of this; the courts are inclined to grant enforcement of awards made in the institutional

\footnotetext{
${ }^{112}$ Chinwe Umegbolu, Behind the legal frustration <https://research.brighton.ac.uk/en/publications/behind-the-legal-frustration> accessed 5th February 2020
} 


\section{The Workings of International Commercial Arbitration (ICA)}

arbitration. Thus, the unnecessary delay will be avoided in the arbitral process.

By and large even though the litigation process gives teeth to the enforcement of the agreement of the arbitration awards. In this writer's view, arbitration is a preferable alternative due to its less complicated nature and simple proceedings. It will have more relevance, development, significance and structure in modern-day dispute resolution methods.

\section{Bibliography}

\section{Primary Sources}

\section{Cases}

Dolling-Baker v Merrett [1990] 1 WLR 1205.

Amoco v British American Offshore Ltd [2001] EWHC 48 (Comm)

Ariori \& Ors v Muraino Elemo \& Ors [1983] LPELR-SC80/1981.

Agu v Ikewibe [1991] 3 N.W.L.R

Ali Shipping Corporation v Shipyard Trogir [1997] EWCA Civ 3054.

Boxer Capital Corp v JEL Investments Ltd [2013] BSCS 2366.

Christopher Brown Ltd $v$ Genossenschaft Osterreichischer Waldbestizer GmbH [1954] 1QB 8.

Dunnett v Rail track Plc [2002] 1 WLR 2434.

Dolling-Baker v Merret [1990] 1 WLR 1205.

Fiona Trust Holding Corp v Privalov [2007] EWCA Civ20.

Foli v Obenge Akese [1934] 1W.A.C.A 46 Privy Council.

General Motors Corporation v Pamela Equities Corporation [1998] UNSCA 146F.3D242. 
Hasley v Milton Keynes General NHS Trust [2004] 1WLR 3002

HKL Group Co Ltd v Rizq International Holdings Pte Ltd [2013] SGHCR 8 .

Jivraj v Hashwani [2011] UKSC 40.

Mitsubishi Motors Corp. v Soler Chrysler-Plymouth, Inc, [1985]. 473 U.S.614, 633.

Morrison v Circuit City Stores, Inc [2003] 317 F.3d 646'664 (6 ${ }^{\text {th }}$ Cir). MRI Trading AG v Erdenet Mining Corp LLC [201O] EWCA Civ 156. Printing and Numerical Registry Co v Sampson [1982] EWCA Civ 5. PGF II SA v OMFS Coy [2013] EWCA Civ 1288.

Ust-Kamenogorsk Hydropower Plant JSC v AES Ust-Kamenogorsk Hydropower Plant LLP [2013] UKSC 35.

$X$ Holding AG and Ors $v$ Y Investments NV ('Xv Y') [2010] SSC.

\section{Legislation}

Civil procedure Rules 1998, Part 31.

The IBA Rules on the taking of Evidence in International Arbitration 2010, Article 3.

United Nations Convention on the Recognition and Enforcement of Foreign Arbitral Awards (New York Convention 1958)

The New York Convention 1958, Art.II (2).

\section{Secondary Sources}

\section{Books}




\section{The Workings of International Commercial Arbitration (ICA)}

Born G, International Arbitration: Law and Practice (Wolters Kluwer Law \& Business 2012)

Born, G, International Litigation \& Arbitration The Principle of Judicial Non Interference in International Arbitral Proceedings (Penn Law: Legal Scholarship Repository)

Brooker P, Mediation Law: Journey through Institutionalism to Juridification (Routledge 2013)

Blake S, Brown J, Sime S, A Practical Approach to Alternative Dispute Resolution (2 ${ }^{\text {nd }}$ edn, Oxford University Press 2011) 31.

Lew J, Mistelis L, Kroll S, Comparative International Commercial Arbitration (Kluwer law International 2003)

Redfern A, Hunter $\mathrm{M}$ et al, Redfern and Hunter on International Arbitration ( $5^{\text {th }}$ edn, Student Version Oxford University Press 2009)

Sutton D, Gill J, Gearing M, Russell on Arbitration (23 ${ }^{\text {rd }}$ edn, Sweet \& Maxwell 2007)

Tackaberry J, Marriot A, Bernstein's Handbook of Arbitration and Dispute Resolution Practice (4 ${ }^{\text {th }}$ edn, Volume 1 Sweet \& Maxwell in Conjunction with the Chartered Institute of Arbitrators 2003)

Mustill M, Boyd S, Commercial Arbitration ( $2^{\text {nd }}$ edn, Butterworths London and Edinburgh 1989).

Moses M, The Principles and Practice of International Commercial Arbitration ( $2^{\text {nd }}$ edn, Cambridge University Press 2012)

Ojukwu E, Ojukwu C, Principles of Civil Procedure in Nigeria (Helen Roberts Research and Resources Ltd 2002).

Onyema, Emilia, The Doctrine of Separability Under Nigerian Law (2009). SOAS School of Law Research Paper No. 03-2010, Apogee Journal of Business, Property \& Constitutional Law, Vol. 1, No. 1, 2009.

Paulsson J, The idea of Arbitration (Oxford University Press 2013) 


\section{Journals and Articles}

Appel M, Taking Your Case to the International Centre for Dispute Resolution (International Centre for Dispute Resolution)

<https://www.adr.org > accessed 7th July 2019.

Baker M, Rogers J, Edge M (eds), Norton Rose Fulbright (1 International arbitration report 2013)

Brewer, Thomas J. "The Arbitrability of Antitrust Disputes: Freedom to Contract for an Alternative Forum." Antitrust Law Journal, vol. 66, no. 1,1997

Bermann G, The "Gateway" Problem in International Commercial Arbitration (2012) 37 (1) The Yale Journal of International law, 10-11 <http:// www.yjil.org/docs/pub > accessed $1^{\text {st June } 2019 .}$

Friedland Paul, Mistelis L, International Arbitration Survey: Choices in International Arbitration (School of International Arbitration at Queen, University of London 2010) .

Umegbolu C, To What Extent is Arbitration a Cheaper and more Efficient Process of Dispute Resolution - in Comparison to Litigation? (A thesis submitted to Kingston University London in partial fulfilment of the requirement for the award of LLM in Dispute Resolution Business Law, August, 2013

Umegbolu, C, Dispensation of justice: the LMDC as a Case Study (On-going PhD research at the University of Brighton 2018-2021)

Umegbolu, Chinwe, Case Review: The Validity of Arbitration Clause and Anti Suit Injunction Revisited (Research Brighton University 2019

Vial, Gonzalo, Influence of the Arbitral Seat in the Outcome of an International Commercial Arbitration Published in Cooperation with SMU Dedman School of Law 2017) 


\section{The Workings of International Commercial Arbitration (ICA)}

Ogar O, International Commercial Arbitration: The Principal Issues and Conflicts of Laws Challenges in Disputes Resolution (A dissertation submitted to the University of Bradford School of Management in partial fulfilment of the requirement for the award of LLM in International Business Law, August, 2013).

IBA Rules on the Taking of Evidence in International Arbitration (International bar Association 2010)

Hacking D, 'Well, Did You Get the Right Arbitrator?' (2000) 15 Mealey's International Arbitration Report 32.

Rose N, Civil Procedure Rules: 10 Years Change (The Law Society Gazette 2014)

<www.lawgazette.co.uk> accessed $2^{\text {nd }}$ July 2019.

Silberberg H, Pontrelli M, To Arbitrate or Not to Arbitrate? (1983) Preventive Law Reporter

Sime S, French D, Blackstone's Guide to the Civil Justice Reforms (Oxford University Press 2013).

Drahozal C, Arbitration Costs and Forum Accessibility: Empirical Evidence (2008) 41 U. Mich.JL. Reform 816.

Igbokwe V, The Law and Practice of Customary Arbitration in Nigeria: Agu v Ikewibe and Applicable Law Issues Revisited (2007) 41 Journal of African Law

Stiponawich T, Arbitration: The New Litigation (2010) University of Illinois Law Review 12

\section{Websites}

Commercial Arbitration Rules and Mediation on Procedures including Procedures for Large Complex Commercial Disputes [2013] American Arbitration Association R4 <https:// www.adr.org> accessed $2^{\text {nd }}$ July 2019. 
Umegbolu, Chinwe, Behind the legal frustration

$<$ https://research.brighton.ac.uk/en/publications/behind-the-legalfrustration $>$ accessed 5th February 2020

Summary of Changes Commercial Arbitration Rules (American Arbitration Association 2013) R-21 <https://www.aryme.com/docs/adr> accessed 1st June 2019.

Rose N, Civil Procedure Rules: 10 Years Change (The Law Society Gazette 2014)

<www.lawgazette.co.uk> accessed $2^{\text {nd }}$ July 2019.

LCIA- The London Court of International Arbitration 2010-2014 <https: //www.Icia.org/Dispute_Resolution>accessed 1 ${ }^{\text {st }}$ July 2019. 